\title{
Technical variables influencing the seed germination of winged bean (Psophocarpus tetragonolobus) seed
}

\author{
*Minh, N.P. \\ Faculty of Biotechnology, Binh Duong University, Vietnam
}

\begin{abstract}
Article history:
Received: 6 June 2021

Received in revised form: 1 July 2021

Accepted: 5 September 2021 Available Online: 3 October 2021
\end{abstract}

\section{Keywords:}

Winged bean,

Soaking sprouting,

Length,

Vitamin C,

Total phenolic,

Overall acceptance

DOI:

https://doi.org/10.26656/fr.2017.5(5).406

\begin{abstract}
The demand for sprouted seeds as dietetics and exotic healthy foods has recently increased. Winged bean seeds contain both nutritional composition and antinutrients. In order to convert this seed into healthy food, the winged bean was germinated into a vegetable sprout. In this research, the influence of soaking and sprouting conditions on the physicochemical and sensory attributes of sprouts was observed. Results showed that winged bean should be soaked in water at $34^{\circ} \mathrm{C}$ in $7 \mathrm{hrs}$, water to solid $3 / 1$. The soaked seed was drained for 15 mins and incubated at temperature $36^{\circ} \mathrm{C}$ for $18 \mathrm{hrs}$. Following these parameters, the winged bean sprout achieved extended length $(46.25 \pm 0.02 \mathrm{~mm})$, vitamin C $(124.13 \pm 0.01 \mathrm{mg} / 100 \mathrm{~g})$, total phenolic content $(997.34 \pm 1.14 \mathrm{mg}$ GAE/100 g) and overall acceptance $(8.94 \pm 0.02)$. Soaking terms for sprouting could improve the nutritional attribute of the winged bean as a functional foodstuff.
\end{abstract}

\section{Introduction}

Sprouting is a simple and cheap method to provide healthy foodstuffs with high yield, without complicated utensils, in a short production cycle in a small warehouse (Delian et al., 2015; Kyriacou et al., 2016; Paolo et al., 2019). Germination begins with water absorption and terminates with the extension of the embryo axis. Physical and biochemical changes occur during this process (Logan et al., 2001). Sprouting induces a mild accumulation of the total polyphenolic content (AlvarezJubete et al., 2010; Pal et al., 2016). The ascorbic acid content in legumes is quite low, those accumulated greatly in sprouted barley (Danisova et al., 1994) and wheat (Yang et al., 2001; Plaza et al., 2003) is due to its de novo synthesis (Lemmens et al., 2018). Germination induces the accumulation of total phenolic content in lupin seeds (Duenas et al., 2009). The ascorbic acid content in mung beans increases during germination (Shah et al., 2011) and directly alters the total phenolic content greatly affecting the antioxidant capacity of sprouts (Lopez-Amoros et al., 2006). In germination, the cell wall degrades to release free phenolics (Gujral et al., 2011). Modification of total phenolic content was also noticed on sorghum sprout (Sorour et al., 2017). Total phenolic content was degraded dramatically in germinated peanut and soybeans due to enzymatic reactions (Megat and Azrina, 2012). In rice sprouting, a high amount of antioxidants, bioactive substances and antioxidant activity were accumulated (Maninder et al., 2017).

Winged bean (Psophocarpus tetragonolobus) seed is an underutilized legume with beneficial nutritional composition (protein, fat, carbohydrate, mineral) and antinutrient (tannin and phytate) (Taofeek et al., 2019). Winged bean seed is highly appreciated as compared to soybean in respect of its excellent nutritional value and high yield but limited to the amino acid cysteine and methionine (Novelina et al., 2013; Vatanparast et al., 2016). Their sprout can be processed into a drink (Novelina et al., 2013) despite its unpleasant flavour due to the activity of lipoxygenase. Sprouting is an effective approach to overcome the rotten feeling from this bean. Lipoxygenase activity was eliminated $77 \%$ of the original activity after $120 \mathrm{hrs}$ of germination (Richard and Prapasri, 2006). The main objective of our study was to observe the effect of soaking and sprouting conditions on the sprout length, total phenolic content, vitamin $\mathrm{C}$ and sensory attribute of sprouts.

\section{Materials and methods}

\subsection{Materials}

Winged bean seed was collected from the gardens in Soc Trang province, Vietnam. It was dried under 
sunlight to $14 \%$ moisture content and kept in a cool place. Chemical reagents were all analytical grade $(>$ 99\% in purity) purchased from Rainbow Trading Co. Ltd., Vietnam.

\subsection{Experiments}

Experiment 1: Effect of soaking temperature on physicochemical and sensory properties of sprouts. The seed was soaked in water at different temperatures (30, $32,34,36,38^{\circ} \mathrm{C}$ ) within $4 \mathrm{hrs}$, with a water to solid ratio of $1 / 1$. The soaked seed was drained for 15 mins before incubation at $30^{\circ} \mathrm{C}$ for $6 \mathrm{hrs}$. The sprout was then collected for physicochemical and sensory evaluation to define the optimal soaking temperature.

Experiment 2: Effect of soaking time on physicochemical and sensory properties of sprouts. The seed was soaked in water at $34^{\circ} \mathrm{C}$ in different durations $(4,5,6,7,8 \mathrm{hrs})$, water to solid ratio $1 / 1$. The soaked seed was drained 15 mins before incubation at $30^{\circ} \mathrm{C}$ for 6 hrs. The sprout was collected for physicochemical and sensory evaluation to define the optimal soaking time.

Experiment 3: Effect of water to seed ratio during soaking to physicochemical and sensory properties of sprout. The seed was soaked in water at $34^{\circ} \mathrm{C}$ for $7 \mathrm{hrs,}$ with different ratios of water to solid $(1 / 1,2 / 1,3 / 1,4 / 1$, $5 / 1)$. The soaked seed was drained for 15 mins before incubating at $30^{\circ} \mathrm{C}$ for $6 \mathrm{hrs}$. The sprouts were collected ready for physicochemical and sensory evaluation to define the optimal water to seed ratio.

Experiment 4: Effect of sprouting temperature on physicochemical and sensory properties of sprouts. The seed was soaked in water at $34^{\circ} \mathrm{C}$ for $7 \mathrm{hrs}$, water to solid $3 / 1$. The soaked seed was drained for 15 mins. Incubation was conducted different temperatures $(30,32$, $34,36,38^{\circ} \mathrm{C}$ ) for $6 \mathrm{hrs}$. The sprout was collected for physicochemical and sensory evaluation to define optimal sprouting temperature.

Experiment 5: Effect of sprouting time on physicochemical and sensory properties of sprouts. The seed was soaked in water at $34^{\circ} \mathrm{C}$ for $7 \mathrm{hrs}$, water to solid $3 / 1$. The soaked seed was drained for 15 mins. Incubation was conducted at temperature $36^{\circ} \mathrm{C}$ in different durations $(6,12,18,24,30$ hours). The sprouts were then collected for physicochemical and sensory evaluation to define optimal sprouting time.

The target function in each experiment was based on the length of sprout $(\mathrm{mm})$, vitamin $\mathrm{C}(\mathrm{mg} / 100 \mathrm{~g})$ and overall acceptance.

\subsection{Physicochemical evaluation}

Length of sprout (mm) was measured by millimetre tape. Vitamin C content (mg/100 g) was quantified according to the method described by AOAC (2005). Total phenolic content (mg GAE/100 g) was estimated by Folin-Ciocalteu reagent assay (Singleton and Rossi, 1965). Overall acceptance was evaluated by a group of panellists using a 9-point Hedonic scale.

\subsection{Statistical analysis}

The demonstrations were prepared as three replicates for various sample groups. The values were expressed as mean \pm standard deviation. The statistical analysis was done using Statgraphics version XVI.

\section{Results and discussion}

\subsection{Effect of soaking temperature to physicochemical} and sensory properties of sprout

Soaking temperature significantly affected the physicochemical and sensory attributes of sprouts (Table 1). When the soaking temperature increased in the range of $30-34^{\circ} \mathrm{C}$, the sprout length extended from $24.71 \pm 0.03$ to $29.14 \pm 0.03 \mathrm{~mm}$. When the soaking temperature surpassed $34^{\circ} \mathrm{C}$, the sprout length slightly decreased. Similarly, other parameters of vitamin C $(39.46 \pm 0.01$ to $62.27 \pm 0.01 \mathrm{mg} / 100 \mathrm{~g}$ ), total phenolic content (187.40 \pm 1.21 to $349.06 \pm 1.28 \mathrm{mg}$ GAE/100 g) and overall acceptance ( $4.19 \pm 0.01$ to $6.13 \pm 0.02)$ was also noticed when soaking temperature increased in the range of $30-$ $34^{\circ} \mathrm{C} .34^{\circ} \mathrm{C}$ was the optimal soaking temperature. In soaking, different complicated components were broken down into simpler substances by biological reactions (Narsih and Harijono, 2012). The 6 hrs soaking induced the extension of the pistachio shoot (Esmaeilpour and Damme, 2016). When soaking at $33^{\circ} \mathrm{C}$, the total phenolic content in germinated brown rice was noticed at the highest level of $33.95 \mathrm{mg} / 100 \mathrm{~g}$ (Kanjana et al., 2017).

\subsection{Influence of soaking time on physicochemical and sensory properties of sprout}

The effect of soaking time on physicochemical and sensory attributes of sprouts was expressed in Table 2. Sprout length, vitamin C, total phenolic content, overall acceptance increased dramatically when the soaking time extended to $7 \mathrm{hrs}$. There was no significant difference between 7 and $8 \mathrm{hrs}$ in respect of mentioned parameters. Within $7 \mathrm{hrs}$ of soaking, sprout length $(34.08 \pm 0.03 \mathrm{~mm})$, vitamin $C(76.49 \pm 0.01 \mathrm{mg} / 100 \mathrm{~g})$, total phenolic content $(587.34 \pm 1.09 \mathrm{mg}$ GAE/100 g), overall acceptance (7.25 \pm 0.04$)$ were recorded. Soaking time in $7 \mathrm{hrs}$ was selected for the next experiments. After soaking for 300 mins, the total phenolic content in germinated brown rice was observed at the highest level at $33.95 \mathrm{mg} / 100 \mathrm{~g}$ (Kanjana et al., 2017). Steeping for $24 \mathrm{hrs}$ at $31^{\circ} \mathrm{C}$ was suitable for sorghum germination (Sharma et al., 2015). 
Table 1. Effect of soaking temperature to physicochemical and sensory properties of sprout

\begin{tabular}{lccccc}
\hline Soaking temperature $\left({ }^{\circ} \mathrm{C}\right)$ & 30 & 32 & 34 & 36 & 38 \\
\hline Sprout length $(\mathrm{mm})$ & $24.71 \pm 0.03^{\mathrm{c}}$ & $25.39 \pm 0.02^{\mathrm{bc}}$ & $29.14 \pm 0.03^{\mathrm{a}}$ & $28.09 \pm 0.01^{\mathrm{ab}}$ & $26.85 \pm 0.02^{\mathrm{b}}$ \\
Vitamin C $(\mathrm{mg} / 100 \mathrm{~g})$ & $39.46 \pm 0.01^{\mathrm{c}}$ & $45.15 \pm 0.03^{\mathrm{bc}}$ & $62.27 \pm 0.01^{\mathrm{a}}$ & $56.33 \pm 0.00^{\mathrm{ab}}$ & $50.28 \pm 0.03^{\mathrm{b}}$ \\
Total phenolic $(\mathrm{mg} \mathrm{GAE} / 100 \mathrm{~g})$ & $187.40 \pm 1.21^{\mathrm{c}}$ & $246.19 \pm 1.34^{\mathrm{bc}}$ & $349.06 \pm 1.28^{\mathrm{a}}$ & $301.25 \pm 1.04^{\mathrm{ab}}$ & $274.31 \pm 1.15^{\mathrm{b}}$ \\
Overall acceptance & $4.19 \pm 0.01^{\mathrm{c}}$ & $4.57 \pm 0.03^{\mathrm{bc}}$ & $6.13 \pm 0.02^{\mathrm{a}}$ & $5.61 \pm 0.01^{\mathrm{ab}}$ & $5.02 \pm 0.03^{\mathrm{b}}$ \\
\hline
\end{tabular}

Values are presented as mean $\pm \mathrm{SD}, \mathrm{n}=3$. Values with the same superscript within the same row are not significantly different ( $\alpha$ $=5 \%$ ).

Table 2. Effect of soaking time to physicochemical and sensory properties of sprout

\begin{tabular}{lccccc}
\hline Soaking time (hours) & 4 & 5 & 6 & 7 & 8 \\
\hline Sprout length (mm) & $29.14 \pm 0.03^{\mathrm{c}}$ & $30.08 \pm 0.00^{\mathrm{bc}}$ & $31.25 \pm 0.01^{\mathrm{b}}$ & $34.08 \pm 0.03^{\mathrm{a}}$ & $34.15 \pm 0.02^{\mathrm{a}}$ \\
Vitamin C (mg/100 g) & $62.27 \pm 0.01^{\mathrm{c}}$ & $65.47 \pm 0.02^{\mathrm{bc}}$ & $69.23 \pm 0.00^{\mathrm{b}}$ & $76.49 \pm 0.01^{\mathrm{a}}$ & $76.83 \pm 0.03^{\mathrm{a}}$ \\
Total phenolic (mg GAE/100 g) & $349.06 \pm 1.28^{\mathrm{c}}$ & $396.10 \pm 1.46^{\mathrm{bc}}$ & $452.09 \pm 1.28^{\mathrm{b}}$ & $587.34 \pm 1.09^{\mathrm{a}}$ & $590.21 \pm 1.32^{\mathrm{a}}$ \\
Overall acceptance & $6.13 \pm 0.02^{\mathrm{c}}$ & $6.45 \pm 0.00^{\mathrm{bc}}$ & $6.83 \pm 0.03^{\mathrm{b}}$ & $7.25 \pm 0.04^{\mathrm{a}}$ & $7.09 \pm 0.02^{\mathrm{ab}}$ \\
\hline
\end{tabular}

Values are presented as mean $\pm \mathrm{SD}, \mathrm{n}=3$. Values with the same superscript within the same row are not significantly different $(\alpha$ $=5 \%)$.

Foxtail millet accumulated the highest total phenolic content after soaking in portable water at ambient temperature (Sharma et al., 2015). During $24 \mathrm{hrs}$ of soaking, there was an accumulation of total phenolics in brown rice (Bishnoi et al., 1994) and wheat (Yang et al., 2001).

3.3 Impact of water to seed ratio during soaking to physicochemical and sensory properties of sprout

Effect of water/seed ratio to physicochemical and sensory attributes of sprout was expressed in Table 3 . The more water incorporated (1/1 to $4 / 1)$, the longer sprout length was recorded (34.08 \pm 0.03 to $38.50 \pm 0.07$ $\mathrm{mm})$. However, vitamin $\mathrm{C}(76.49 \pm 0.01$ to $87.14 \pm 0.01$ $\mathrm{mg} / 100 \mathrm{~g})$, total phenolic content $(587.34 \pm 1.09$ to $736.54 \pm 1.14 \mathrm{mg}$ GAE$/ 100 \mathrm{~g}$ ), and overall acceptance ( $7.25 \pm 0.04$ to $8.01 \pm 0.00$ ) accumulated significantly when the water/seed ratio increased from $1 / 1$ to $3 / 1$. When water was added to the seeds at $4 / 1$ or $5 / 1$, vitamin $C$ $(85.16 \pm 0.03$ to $83.46 \pm 0.02 \mathrm{~mm})$, total phenolic content $(694.16 \pm 1.18 \mathrm{mg} \mathrm{GAE} / 100 \mathrm{~g})$, and overall acceptance (7.83 \pm 0.01 to $7.72 \pm 0.03)$ gradually decreased. Therefore, the water/seed ratio was fixed at $3 / 1$ for the next experiments. Moisture penetrates the seeds through the membrane by diffusion as a result of the accumulation of endogenous osmotica (Obroucheva and Antipova, 1997; Obroucheva et al., 2017). Moisture inflow into cells happened through water channels made by plasmalemma aquaporins (Trofimova et al., 2001; Javot and Maurel, 2002). The proteolysis of reserve proteins initiated by proteinases if the moisture content in embryonic axes reached about 45-55\% (Muntz et al., 2001). At moisture of $55-65 \%$, the degradation of legumin induced by endopeptidases originated from the cytoplasm (Lichtenfeld et al., 1979). At moisture of $68 \%$, vacuoles were rather visible and enlarged, ready for further absorption.

\subsection{Effect of sprouting temperature to physicochemical and sensory properties of sprout}

The influence of sprouting temperature on sprout length, vitamin $\mathrm{C}$, total phenolic content, overall acceptance was presented in Table 4. Sprout length (36.85 \pm 0.02 to $41.25 \pm 0.03 \mathrm{~mm})$, vitamin $\mathrm{C}(87.14 \pm 0.01$ to $96.14 \pm 0.02 \mathrm{mg} / 100 \mathrm{~g}$ ), total phenolic content (736.54 \pm 1.14 to $897.47 \pm 1.09 \mathrm{mg} \mathrm{GAE} / 100 \mathrm{~g}$ ), and overall acceptance $(8.01 \pm 0.00$ to $8.64 \pm 0.02)$ greatly improved when the sprouting temperature increased from 30 to $36^{\circ} \mathrm{C}$. At $38^{\circ} \mathrm{C}$, those aforementioned parameters decreased gradually. Hence, optimal sprouting temperature was chosen at $36^{\circ} \mathrm{C}$ for the next experiment. $30^{\circ} \mathrm{C}$ was optimal for maximum sprouting, stem length and yield from mungbean seed (Muhammad et al., 2019). A temperature of $35^{\circ} \mathrm{C}$ was ideal for sprouting

Table 3. Effect of water to seed ratio during soaking to physicochemical and sensory properties of sprout

\begin{tabular}{lccccc}
\hline Water to seed ratio & $1 / 1$ & $2 / 1$ & $3 / 1$ & $4 / 1$ & $5 / 1$ \\
\hline Sprout length (mm) & $34.08 \pm 0.03^{\mathrm{c}}$ & $35.46 \pm 0.05^{\mathrm{bc}}$ & $36.85 \pm 0.02^{\mathrm{b}}$ & $37.69 \pm 0.02^{\mathrm{ab}}$ & $38.50 \pm 0.07^{\mathrm{a}}$ \\
Vitamin C (mg/100 g) & $76.49 \pm 0.01^{\mathrm{c}}$ & $81.23 \pm 0.03^{\mathrm{bc}}$ & $87.14 \pm 0.01^{\mathrm{a}}$ & $85.16 \pm 0.03^{\mathrm{ab}}$ & $83.46 \pm 0.02^{\mathrm{b}}$ \\
Total phenolic (mg GAE/100 g) & $587.34 \pm 1.09^{\mathrm{c}}$ & $628.14 \pm 1.37^{\mathrm{bc}}$ & $736.54 \pm 1.14^{\mathrm{a}}$ & $694.16 \pm 1.18^{\mathrm{ab}}$ & $662.08 \pm 1.05^{\mathrm{b}}$ \\
Overall acceptance $^{\mathrm{b}}$ & $7.25 \pm 0.04^{\mathrm{c}}$ & $7.54 \pm 0.03^{\mathrm{bc}}$ & $8.01 \pm 0.00^{\mathrm{a}}$ & $7.83 \pm 0.01^{\mathrm{ab}}$ & $7.72 \pm 0.03^{\mathrm{b}}$ \\
\hline
\end{tabular}

Values are presented as mean $\pm \mathrm{SD}, \mathrm{n}=3$. Values with the same superscript within the same row are not significantly different ( $\alpha$ $=5 \%)$. 
Table 4. Effect of sprouting temperature to physicochemical and sensory properties of sprout

\begin{tabular}{lccccc}
\hline Sprouting temperature $\left({ }^{\circ} \mathrm{C}\right)$ & 30 & 32 & 34 & 36 & 38 \\
\hline Sprout length $(\mathrm{mm})$ & $36.85 \pm 0.02^{\mathrm{c}}$ & $37.62 \pm 0.03^{\mathrm{bc}}$ & $38.33 \pm 0.01^{\mathrm{b}}$ & $41.25 \pm 0.03^{\mathrm{a}}$ & $40.07 \pm 0.04^{\mathrm{ab}}$ \\
Vitamin C (mg/100 g) & $87.14 \pm 0.01^{\mathrm{c}}$ & $89.40 \pm 0.00^{\mathrm{bc}}$ & $91.63 \pm 0.03^{\mathrm{b}}$ & $96.14 \pm 0.02^{\mathrm{a}}$ & $93.84 \pm 0.00^{\mathrm{ab}}$ \\
Total phenolic $(\mathrm{mg} \mathrm{GAE} / 100 \mathrm{~g})$ & $736.54 \pm 1.14^{\mathrm{c}}$ & $772.46 \pm 1.11^{\mathrm{bc}}$ & $811.24 \pm 1.06^{\mathrm{b}}$ & $897.47 \pm 1.09^{\mathrm{a}}$ & $864.08 \pm 1.01^{\mathrm{ab}}$ \\
Overall acceptance & $8.01 \pm 0.00^{\mathrm{c}}$ & $8.17 \pm 0.02^{\mathrm{bc}}$ & $8.35 \pm 0.03^{\mathrm{b}}$ & $8.64 \pm 0.02^{\mathrm{a}}$ & $8.50 \pm 0.01^{\mathrm{ab}}$ \\
\hline
\end{tabular}

Values are presented as mean $\pm \mathrm{SD}, \mathrm{n}=3$. Values with the same superscript within the same row are not significantly different $(\alpha$ $=5 \%$ ).

black gram (Danaipot et al. 2015). Sorghum should be sprouted within 4.5 days at $30^{\circ} \mathrm{C}$ to obtain the highest total phenolic content (Sharma et al., 2015). The highest total phenolic content was obtained in the germination of grain at $28^{\circ} \mathrm{C}$ for $96 \mathrm{hrs}$ (Caceres et al., 2014). The highest total phenolic content in wheat sprouts was obtained after 7 days of germination at $16.5^{\circ} \mathrm{C}$ (Yang et al., 2001). The optimal temperature for rambutan sprouting was $25^{\circ} \mathrm{C}$ in six days (Renata et al., 2017).

3.5 Effect of sprouting time to physicochemical and sensory properties of sprout

Effect of sprouting time to sprout length, vitamin C, total phenolic content and overall acceptance was elaborated in Table 5. The longer the sprouting time was extended (6-30), the longer the length of the sprout $(41.25 \pm 0.03$ to $52.64 \pm 0.02 \mathrm{~mm})$. However, vitamin C $(124.13 \pm 0.01 \mathrm{mg} / 100 \mathrm{~g})$, total phenolic content $(997.34 \pm 1.14 \mathrm{mg}$ GAE$/ 100 \mathrm{~g})$ and overall acceptance $(8.94 \pm 0.02)$ could be obtained at $18 \mathrm{hrs}$ of sprouting. Soaking cashew nuts in water for 24 or $36 \mathrm{hrs}$ in advance of sowing resulted in high cashew crop (Oyewole and Koffa, 2010). In waxy wheat, the total phenolic content dropped after 12 and $24 \mathrm{hrs}$ of sprouting and then greatly accelerated after 36 and 48 hrs (Hung et al., 2012). In brown rice, both free- and bound- fragments greatly increased over the sprouting period owing to the hydrolysis of conjugated phenolic components (Ti et al., 2014; Zilic et al., 2014). Foxtail millet accumulated the highest total phenolic content after $40 \mathrm{hrs}$ of sprouting at $25^{\circ} \mathrm{C}$ (Sharma et al., 2015). Purple corn sprouts had the highest total phenolic content by sprouting at $26^{\circ} \mathrm{C}$ for $63 \mathrm{hrs}$ (Paucar-Menacho et al., 2017). Sprouted quinoa received much more phenolics by germination at $20^{\circ} \mathrm{C}$ for 42 hrs (Paucar-Menacho et al., 2018). The antioxidant activity of germinated seeds was affected by sprouting duration (Suryanti et al., 2016)

\section{Conclusion}

The Winged bean is an underexploited tropical leguminous plant. Its seed attracts great commercial interest mainly due to its proximate composition. It can be considered as an alternative for soybean with similar characteristics. Successfully observed changes of sprout length, total phenolic content, vitamin $\mathrm{C}$ and organoleptic attribute under different conditions of soaking (time, temperature, water to solid ratio) and germination (time and temperature) were recorded. Sprouts from winged beans would be as beneficial for human health as green vegetables.

\section{Conflict of interest}

The author strongly confirms that this research was conducted with no conflict of interest.

\section{Acknowledgement}

We acknowledge the financial support for the publication provided by Binh Duong University, Vietnam.

\section{References}

Alvarez-Jubete, L., Wijngaard, H., Arendt, E.K. and Gallagher, E. (2010). Polyphenol composition and in vitro antioxidant activity of amaranth, quinoa buckwheat and wheat as affected by sprouting and baking. Food Chemistry, 119(2), 770-778. https:// doi.org/10.1016/j.foodchem.2009.07.032

AOAC. (2005). Official method of analysis. 18th ed. Washington, D.C., USA: Association of Official Analytical Chemists.

Table 5. Effect of sprouting time to physicochemical and sensory properties of sprout

\begin{tabular}{lccccc}
\hline Soaking time (hours) & 6 & 12 & 18 & 24 & 30 \\
\hline Sprout length (mm) & $41.25 \pm 0.03^{\mathrm{c}}$ & $43.59 \pm 0.01^{\mathrm{bc}}$ & $46.25 \pm 0.02^{\mathrm{b}}$ & $49.37 \pm 0.00^{\mathrm{ab}}$ & $52.64 \pm 0.02^{\mathrm{a}}$ \\
Vitamin C (mg/100 g) & $96.14 \pm 0.02^{\mathrm{c}}$ & $105.37 \pm 0.03^{\mathrm{bc}}$ & $124.13 \pm 0.01^{\mathrm{a}}$ & $115.28 \pm 0.03^{\mathrm{ab}}$ & $108.30 \pm 0.01^{\mathrm{b}}$ \\
Total phenolic (mg GAE/100 g) & $897.47 \pm 1.09^{\mathrm{c}}$ & $925.68 \pm 0.85^{\mathrm{bc}}$ & $997.34 \pm 1.14^{\mathrm{a}}$ & $980.41 \pm 1.04^{\mathrm{ab}}$ & $957.12 \pm 1.25^{\mathrm{b}}$ \\
Overall acceptance & $8.64 \pm 0.02^{\mathrm{c}}$ & $8.71 \pm 0.00^{\mathrm{bc}}$ & $8.94 \pm 0.02^{\mathrm{a}}$ & $8.86 \pm 0.01^{\mathrm{ab}}$ & $8.80 \pm 0.00^{\mathrm{b}}$ \\
\hline
\end{tabular}

Values are presented as mean $\pm \mathrm{SD}, \mathrm{n}=3$. Values with the same superscript within the same row are not significantly different ( $\alpha$ $=5 \%$ ) 
Bishnoi, S., Khetarpaul, N. and Yadav, R.K. (1994). Effect of domestic processing and cooking methods on phytic acid and polyphenol content of peas. Plant Foods for Human Nutrition, 45(4), 381-388. https:// doi.org/10.1007/BF01088088

Caceres, P.J., Martinez-Villaluenga, C., Amigo, L. and Frias, J. (2014). Maximising the phytochemical content and antioxidant activity of Ecuadorian brown rice sprouts through optimal germination conditions. Food Chemistry, 152(1), 407-414. https:// doi.org/10.1016/j.foodchem.2013.11.156

Danaipot, L., Kullanart, T. and Kriskamol, N.J. (2016). Effect of sprouting temperature and air relative humidity on metabolic profiles of sprouting black gram (Vigna mungo L.). Journal of Food Processing and Preservation, 40(2), 306-315. https:// doi.org/10.1111/jfpp. 12608

Danisova, C., Holotnakova, E., Hozova, B. and Buchtova, V. (1994). Effect of germination on a range of nutrients of selected grains and legumes. Acta Alimentaria, 23(3), 287-298.

Duenas, M., Hernandez, T., Estrella, I. and Fernandez, D. (2009). Germination as a process to increase the polyphenol content and antioxidant activity of lupin seeds (Lupinus angustifolius L.). Food Chemistry, 117(4), 599-607. https://doi.org/10.1016/ j.foodchem.2009.04.051

Esmaeilpour, A. and Damme, P.V. (2016). Evaluation of seed soaking times on germination percentage, germination rate and growth characteristics of pistachio seedlings. Acta Horticulture, 1109, 107112. https://doi.org/10.17660/ ActaHortic.2016.1109.17

Gujral, H.S., Sharma, P., Kumar, A. and Singh, B. (2012). Total phenolic content and antioxidant activity of extruded brown rice. International Journal of Food Properties, 15(2), 301-311. https:// doi.org/10.1080/10942912.2010.483617

Hung, V.P., Maeda, T., Yamamoto, S. and Morita, N. (2012). Effects of germination on nutritional composition of waxy wheat. Journal Science of Food and Agriculture, 92(3), 667-672. https:// doi.org/10.1002/jsfa.4628

Javot, H. and Maurel, C. (2002). The role of aquaporins in root water uptake. Annals of Botany, 90(3), 301313. https://doi.org/10.1093/aob/mcf199

Kanjana, S., Piyawan, S., Suwanna, D. and Niramon, U. (2017). Effect of soaking temperature and time on GABA and total phenolic content of germinated brown rice (Phitsanulok 2). Current Applied Science and Technology, 17(2), 224-232.

Lichtenfeld, C., Manteuffel, R., Muntz, K., Neumann,
D., Scholz, C. and Weber, E. (1979). Protein degradation and proteolytic activities in germinating field beans (Vicia faba L., var. minor). Biochemie und Physiologie der Pflanzen, 174(4), 255-274. https://doi.org/10.1016/S0015-3796(17)30587-5

Logan, D.C., Millar, A.H., Sweetlove, L.J., Hill, S.A. and Leaver, C.J. (2001). Mitochondrial biogenesis during germination in maize embryos. Plant Physiology, 125(2), 662-672. https:// doi.org/10.1104/pp.125.2.662

Lopez-Amoros, M.L., Hernandez, T. and Estrella, I. (2006). Effect of germination on legume phenolic compounds and their antioxidant activity. Journal Food Composition and Analysis, 19(4), 277-283. https://doi.org/10.1016/j.jfca.2004.06.012

Maninder, K., Bavita, A. and Gulshan, M. (2017). Variation in antioxidants, bioactive compounds and antioxidant capacity in germinated and ungerminated grains of ten rice cultivars. Rice Science, 24(6), 349359. https://doi.org/10.1016/j.rsci.2017.08.002

Megat, R.M.R. and Azrina, A. (2012). Effect of germination on total phenolic, tannin and phytic acid contents in soybean and peanut. International Food Research Journal, 19(2), 673-677.

Muhammad, H., Mansoor, K.K., Inam, U.H., Kausar, G., Ansa, K., Kaleem, U., Ali, K. and Azmat, A. (2019). Effects of temperature and water purity on germination and yield of mungbean sprouts. Sains Malaysiana, 48(4), 711-717. https:// doi.org/10.17576/jsm-2019-4804-02

Muntz, K., Belozersky, M.A., Dunaevsky, Y.E., Schlereth, A. and Tiedermann, J. (2001). Stored proteinases and the initiation of storage protein mobilization in seeds during germination and seedling growth. Journal of Experimental Botany, 52 (362), 1741-1752. https://doi.org/10.1093/ jexbot $/ 52.362 .1741$

Narsih, Y. and Harijon. (2012). The study of germination and soaking time to improve the nutritional quality of sorghum seed. International Food Research Journal, 19(4), 1429-1432.

Novelina, S., Kesuma, N. and Fitri, R. (2013). Characteristics of fermentation drink made from juice of winged bean sprouts (Psophocarpus tetragonolobus) and red sweet potato (Ipomoea batatas). International Journal on Advance Science Engineering Information Technology, 3(6), 1-4. https://doi.org/10.18517/ijaseit.3.6.341

Obroucheva, N.V. and Antipova, O.V. (1997). Physiology of the initiation of seed germination. Russian Journal of Plant Physiology, 44(1), 250264. 
Obroucheva, N.V., Sinkevich, I.A., Lityagina, S.V. and Novikova, G.V. (2017). Water relations in germinating seeds. Russian Journal of Plant Physiology, 64(1), 625-633. https://doi.org/10.1134/ S102144371703013X

Oyewole, C.I. and Koffa, K.J. (2010). Effect of storage, size of nut and soaking length on sprout emergence in cashew. Thai Journal of Agricultural Science, 43 (1), 39-45. https://www.thaiscience.info/journals/ Article/TJAS/10594539.pdf

Pal, P., Singh, N., Kaur, P., Kaur, A., Virdi, A.S. and Parmar, N. (2016). Comparison of composition, protein, pasting, and phenolic compounds of brown rice and germinated brown rice from different cultivars. Cereal Chemistry, 93(6), 584-592. https:// doi.org/10.1094/CCHEM-03-16-0066-R

Paucar-Menacho, L.M., Martinez-Villaluenga, C., Duenas, M., Frias, J. and Penas, E. (2017). Optimization of germination time and temperature to maximize the content of bioactive compounds and the antioxidant activity of purple corn (Zea mays L.) by response surface methodology. LWT-Food Science and Technology, 76(1), 236-244. https:// doi.org/10.1016/j.lwt.2016.07.064

Paucar-Menacho, L.M., Martinez-Villaluenga, C., Duenas, M., Frias, J. and Penas, E. (2018). Response surface optimisation of germination conditions to improve the accumulation of bioactive compounds and the antioxidant activity in quinoa. Internal Journal of Food Science and Technology, 53(2), 516 -524. https://doi.org/10.1111/ijfs.13623

Plaza, L., de Ancos, B. and Cano, P.M. (2003). Nutritional and health-related compounds in sprouts and seeds of soybean (Glycine max), wheat (Triticum aestivum L.) and alfalfa (Medicago sativa) treated by a new drying method. European Food Research Technology, 216(1), 138-144. https:// doi.org/10.1007/s00217-002-0640-9

Renata, A.A., Amanda, G.B. and Guilherme, N. (2017). Rambutan seed germination: temperature and storage. Comunicata Scientiae, 8(2), 383-388. https://doi.org/10.14295/cs.v8i2.2114

Richard, D.K. and Prapasri, P. (2006). Effects of germination on the proximate composition and nutritional quality of winged bean (Psophocarpus tetragonolobus) seeds. Journal of Food Science, 52 (1), 106 - 108. https://doi.org/10.1111/j.13652621.1987.tb13982.x

Shah, S.A., Zeb, A., Masood, T., Noreen, N., Abbas, S.J., Samiullah, M., Alim, M.A. and Muhammad, A. (2011). Effects of sprouting time on biochemical and nutritional qualities of mungbean varieties. African Journal of Agricultural Research, 6(22), 5091-5098.

\section{https://doi.org/10.5897/AJAR11.480}

Sharma, S., Saxena, D.C. and Riar, C.S. (2015). Antioxidant activity, total phenolics, flavonoids and antinutritional characteristics of germinated foxtail millet (Setaria italica). Cogent Food and Agriculture, 1(1), $1081728 . \quad \mathrm{https}: / /$ doi.org/10.1080/23311932.2015.1081728

Singleton, V.L. and Rossi, J.A.J.R. (1965). Colorimetry of total phenolics with phosphomolybdic phosphotungstic acid reagents. American Journal of Enology and Viticulture, 16(3), 144-158.

Sorour, M.A., Mehanni, A.E., Taha, E.M. and Rashwan, A.K. (2015). Changes of total phenolics, tannins, phytate and antioxidant activity of two sorghum cultivars as affected by processing. Journal of Food and Dairy Sciences, 8(7), 267 - 274. https:// doi.org/10.21608/jfds.2017.38699

Suryanti, V., Marliyana, S.D. and Putri, H.E. (2016). Effect of germination on antioxidant activity, total phenolics, $\beta$-carotene, ascorbic acid and $\alpha$ tocopherol contents of lead tree sprouts (Leucaena leucocephala (lmk.) de Wit). International Food Research Journal, 23(1), 167-172.

Taofeek, T.A., Michael, T.A., Abdel, A.H.A.G., Mahamadi, D., Busie, M.D., Olaniyi, A.O., Sam, O. and Olubukola, O.B. (2019). Nutrient and antinutrient composition of winged bean (Psophocarpus tetragonolobus (L.) DC.) seeds and tubers. Journal of Food Quality, 2019, 3075208. https://doi.org/10.1155/2019/3075208

Ti, H., Zhang, R., Zhang, M., Li, Q., Wei, Z., Zhang, Y., Tang, X., Deng, Y., Liu, L. and Ma, Y. (2014). Dynamic changes in the free and bound phenolic compounds and antioxidant activity of brown rice at different germination stages. Food Chemistry, 161 (15), 337-344. https://doi.org/10.1016/ j.foodchem.2014.04.024

Trofimova, M.S., Zhestkova, I.M., Andreev, I.M., Svinov, M.M., Bobylev, Y.S. and Sorokin, E.M. (2001). Osmotic water permeability of vacuolar and plasma membranes isolated from maize roots. Russsian Journal of Plant Physiology, 48(1), 287293. https://doi.org/10.1023/A:1016697813072

Vatanparast, M., Shetty, P. and Chopra, R. (2016). Transcriptome sequencing and marker development in winged bean (Psophocarpus tetragonolobus; Leguminosae). Scientific Reports, 6(1), 29070. https://doi.org/10.1038/srep29070

Yang, F., Basu, T.K. and Ooraikul, B. (2001). Studies on germination: Conditions and antioxidant contents of wheat grain. International Journal of Food Science Nutrition, 52(4), 319-330. https:// 
doi.org/10.1080/09637480120057567

Zilic, S., Basic, Z., Hadzi-Taskovic, S.V., Maksimovic, V., Jankovic, M. and Filipovic, M. (2014). Can the sprouting process applied to wheat improve the contents of vitamins and phenolic compounds and antioxidant capacity of the flour? International Journal of Food Science and Technology, 49(4), 1040-1047. https://doi.org/10.1111/ijfs. 12397 